\title{
Ovarian Signet Ring Stromal Tumor
}

National Cancer Institute

\section{Source}

National Cancer Institute. Ovarian Signet Ring Stromal Tumor. NCI Thesaurus. Code C39965.

A rare, benign sex cord-stromal tumor that arises from the ovary. It is characterized by the presence of round cells with a single cytoplasmic vacuole and an eccentric nucleus resembling signet ring cells. Mucin stains are negative. 